\title{
ENERGY BALANCE AT THE SURFACE OF THE ICE SHEET IN THE COASTAL AREA OF ADÉLIE LAND, ANTARCTICA
}

\author{
(Abstract only) \\ by \\ P.-L. Blaix, D. Delaunay and A. Poggi \\ (Laboratoire de Glaciologie et Géophysique de l'Environnement, 2 rue Très-Cloîtres, \\ 38031 Grenoble Cedex, France)
}

\begin{abstract}
Hourly measurements of wind, temperature, and humidity were made between elevations of 1 and $20 \mathrm{~m}$ in the coastal area of Adélie Land over a period of $45 \mathrm{~d}$ in January and February 1978. About 1000 profiles are available.

The height of the constant flux layer is $>5 \mathrm{~m}$ despite the influence of katabatic winds, the wind profile is logarithmic with a mean standard deviation from the logarithmic law of $15 \mathrm{~mm} \mathrm{~s}$. The potential temperature profile is also logarithmic with a mean standard deviation of $0.04^{\circ} \mathrm{C}$. The most important deviation from the logarithmic law appears between -4 and $0^{\circ} \mathrm{C}$.
\end{abstract}

Humidity was measured at two points only, between 1 and $20 \mathrm{~m}$; the mean gradient was about $0.01 \mathrm{mbar}^{-1}$ and the flux of latent heat was generally negligible.

Net radiation was measured for only $10 \mathrm{~d}$ because of radiometer failure. All the fluxes are calculated using data for the $5 \mathrm{~m}$ layer. For the $10 \mathrm{~d}$ period, the heat loss was about $3 \mathrm{~W} \mathrm{~m}^{-2}$ with a mean heat flux of $-27.5 \mathrm{Wm}^{-2}$ and mean net radiation of $-10.5 \mathrm{Wm}^{-2}$ (the minus sign signifying the flux is towards the surface). In general, the heat flux is towards the surface ( $92 \%$ of the cases) but is away from the surface in the afternoon. The ablation during the $10 \mathrm{~d}$ period without snow-fall was about $200 \mathrm{~mm}$ of ice.

\section{SOME EVIDENCE OF LONG-DISTANCE TRANSPORT, LOCAL SOURCES AND FRACTIONATION BETWEEN AIR AND SNOW} FOR METALLIC AEROSOLS DEPOSITED IN ANTARCTIC SNOWS SINCE THE 1880s

\section{(Abstract only)}

\author{
by \\ P. Buat-Menard* \\ (Graduate School of Oceanography, University of Rhode Island, Kingston, \\ Rhode Island 02881, U.S.A.) \\ and C. Boutron \\ (Laboratoire de Glaciologie et Géophysique de l'Environnement, 2 rue Très-Cloitres, \\ 38031 Grenoble-Cedex, France)

\begin{abstract}
by global atmospheric pollution. These data also confirm that, for several metals, episodes of anomalously high concentrations are in phase with increased sulphate and acidity, which could result from volcanic fallout. However, during such episodes, a straightforward relationship between the rate of increase in trace metals and the rate of increase in sulphate and acidity is not observed. This also affects volatile elements such as $\mathrm{Cl}, \mathrm{Br}$, Se, and $I$. This is probably due to a combined effect of local versus long-range transport of volcanic aerosols together with a physico-chemical segregation between the various components of this aerosol.
\end{abstract}

\begin{abstract}
Using instrumental neutron activation analysis, we have determined the concentrations of $\mathrm{Na}, \mathrm{Cl}, \mathrm{Al}$, $\mathrm{Sc}, \mathrm{V}, \mathrm{Cr}, \mathrm{Mn}, \mathrm{Co}, \mathrm{Fe}, \mathrm{Zn}, \mathrm{As}, \mathrm{Se}, \mathrm{Br}, \mathrm{Sb}$, and $\mathrm{J}$ in ultra-clean dated snow samples collected in central East Antarctica. These samples had been previously analysed by flameless atomic absorption spectrometry (Boutron 1980). For the elements determined by both techniques ( $\mathrm{Na}, \mathrm{Al}, \mathrm{Mn}, \mathrm{Fe}$, and $\mathrm{Zn}$ ) the results are in remarkable agreement. These new data confirm and extend the conclusion that background concentrations of trace elements observed at present in Antarctic snow are close to those observed about 100 a BP and thus that Antarctic aerosol is still little affected
\end{abstract}

*Present address: Centre des Faibles Radioactivités, Laboratoire mixte CNRS-CEA, 91190 Gif sur Yvette, France. 